\title{
The bright and shaded side of duneland life: the photosynthetic response of lichens to seasonal changes is species-specific
}

\author{
Katalin Veres $^{1}$ (D) $\cdot$ Edit Farkas $^{1}$ (D) $\cdot$ Zsolt Csintalan $^{2}$ (D) \\ Received: 7 October 2019 / Revised: 15 April 2020 / Accepted: 21 April 2020 \\ (C) The Author(s) 2020
}

\begin{abstract}
Terricolous lichens are relevant associates of biological soil crusts in arid and semiarid environments. Dunes are ecosystems of high conservation interest, because of their unique, vulnerable and threatened features. The function of lichens is affected by the changing seasons and different microhabitat conditions. At the same time, inland dunes are less investigated areas from the terricolous lichens point of view. We explored the effect of seasonal variation and different micro-environmental conditions (aspect) on the metabolic activity of five terricolous lichen species, representing various growth forms, in temperate semiarid grasslands. Populations of Cladonia foliacea, C. furcata, C. pyxidata group, Diploschistes muscorum and Thalloidima physaroides were investigated. Thalli sampled from the south-west and north-east facing microhabitats were studied by chlorophyll fluorescence analysis for 2 years. The present study aims to understand how changing climate (during the year) and aspect affect photosynthetic activity and photoprotection. Microclimatic data were also continuously recorded to reveal the background of the difference between microhabitat types. As a result, the air temperature, photosynthetically active radiation, soil temperature and vapour pressure deficit were significantly higher on south-west than on north-east facing microsites, where relative humidity and water content of soil proved to be considerably higher. Higher photosynthetic activity, as well as a higher level of photoprotection, was detected in lichens from north-east-oriented microsites compared with south-west populations. In addition, the difference between sun and shade populations varied seasonally. Since a species-specific response to both aspect and season was detected, we propose to investigate more than one species of different growth forms, to reveal the response of lichens to the changing environment in space and time.
\end{abstract}

Keywords Terricolous lichens $\cdot$ Aspect $\cdot$ Microclimate $\cdot$ Photosynthetic activity $\cdot$ Photoprotection $\cdot$ Temperate semiarid sandy grassland

\section{Introduction}

Dunes are dynamic and threatened ecosystems in temperate regions of Central-Europe. These habitats are characterised by

Zsolt Csintalan deceased

Section Editor: Gerhard Rambold

Katalin Veres

veres.katalin@okologia.mta.hu

1 Institute of Ecology and Botany, MTA Centre for Ecological Research, Alkotmány u. 2-4, Vácrátót 2163, Hungary

2 Institute of Botany and Ecophysiology, Szent István University, Páter K. u. 1, Gödöllő 2100, Hungary extreme environmental conditions, where the majority of vascular plants are not able to colonize the available substrates because of their sensitivity (Belnap and Lange 2003). Terricolous lichen associations are more abundant because lichens are able to adapt to these harsh and complex conditions in different ways (e.g. Armstrong 2017; Lange 2001). Among other factors, microtopography plays an essential role in controlling the lichen environment as it affects the overall microclimate between dunes (Tilk et al. 2018). Thalli derived from sun and shade populations of the same lichen species may differ in several aspects, for example in thallus anatomy (e.g. Atala et al. 2015; Dietz et al. 2000; Pintado et al. 2005), pigment composition (e.g. Färber et al. 2014; Gauslaa and Solhaug 2004) and physiological functioning. The photosynthetic activity $\left(\mathrm{F}_{\mathrm{V}} / \mathrm{F}_{\mathrm{M}}\right)$ can be lower in sun than in shade lichen 
populations (e.g. Gauslaa et al. 2006; Pirintsos et al. 2011) or in thalli exposed to sudden changes in light conditions, especially in smaller thalli (Bianchi et al. 2019a).

Besides the long-term effect of different microhabitat conditions, seasonal variation of climate may also cause significant changes in thallus anatomy (e.g. Holopainen 1982; Tretiach et al. 2013) and in photosynthetic functioning (Lange and Green 2003). Schroeter et al. (2011) showed that in Antarctic vegetation, the $\mathrm{F}_{\mathrm{V}} / \mathrm{F}_{\mathrm{M}}$ of Umbilicaria aprina $\mathrm{Nyl}$. was lower in winter compared with summer values. An inverse correlation was found in lichens living in submediterranean oak forests (e.g. Baruffo and Tretiach 2007). In southern Norwegian forests, a peak was observed in this parameter in late autumn and a minimum in spring in the case of Xanthoria parietina (L.) Th. Fr. Similarly, photoprotection (NPQ) also showed a seasonal pattern (Vráblíková et al. 2006). MacKenzie et al. (2002) measured a higher level of photoprotection in Lobaria pulmonaria (L.) Hoffm. in spring than in late summer, but the opposite was observed by Vráblíková et al. (2006). These studies clearly indicate that lichens can adapt to changing environments in different ways. However, these investigations were carried out mostly on epiphytic, forest-living or saxicolous lichens. Terricolous lichens can cover large areas; however, there are only a few studies about how different microenvironmental conditions affect the seasonal changes of photosynthetic functioning of different species in semiarid (temperate zone) grasslands (e.g. Kalapos and Mázsa 2001; Lange and Green 2003). Different climatic conditions fundamentally affect the photosynthetic process of lichens; therefore, it is important to collect information from as many diverse areas and habitat types as possible.

The aim of the present study was to investigate the influence of both microhabitat conditions (aspect) and seasonal changes on photosynthetic activity and photoprotection of several terricolous lichen species. Species of various growth forms were selected because the water household capacity greatly depends on the morphology of these poikilohydric organisms (e.g. Larson 1981; Petruzzellis et al. 2018) and is closely correlated with metabolic functions (e.g. Büdel and Scheidegger 2008; Gauslaa 2014). We hypothesised that populations of the different species would differ in their responses to seasonal climatic changes, because of their special adaptation strategies. To investigate our hypothesis, chlorophyll $a$ fluorescence kinetic measurements were applied, as an adequately sensitive but non-destructive method, for studying the response of photosynthetic organisms to environmental factors (Schreiber et al. 1994). From the measured data, $F_{V} / F_{M}$ and NPQ were calculated as the most frequently used chlorophyll fluorescence variables in ecological investigations. The recorded micrometeorological data revealed the main differences between microhabitat types. This paper presents how terricolous lichen species of different growth forms were able to acclimate to seasonal changes in their photosynthetic activity and photoprotection under different microhabitat conditions.

\section{Materials and methods}

\section{Study sites}

Semiarid sandy grasslands (Festucetum vaginatae association Rapaics ex Soó 1929 em. Borhidi 1996) with many endemic lichens are native vegetation types of the Kiskunság region of Hungary (Gallé 1972-1973), where sandy dunes provide diverse lichen microhabitats. This region is mostly covered by calcareous sandy soil from the Pleistocene deposit of Danube River. The prevailing wind (from north-west to south-east), as a secondary effect, reshaped the landscape resulting in a dune land (Pécsi 1967) with dune sides of north-east (NE) and south-west (SW) aspects. The vegetation is dominated by Festuca vaginata W. et K., Stipa borysthenica Klokov, Fumana procumbens (Dun.) Gren. et Godr., Alcanna tinctoria (L.) Tausch, Dianthus serotinus W. et K., Onosma arenaria W. et K. and Sedum hillebrandtii Fenzl (Borhidi et al. 2012; Fekete 1997). The study area is characterised by a moderately continental climate with a submediterranean influence (Péczely 1967). Three dunes near Bugacpusztaháza ( $46^{\circ} 42^{\prime}$ $\left.7.9^{\prime \prime} \mathrm{N}, 19^{\circ} 38^{\prime} 8.3^{\prime \prime} \mathrm{E}\right)$ were chosen for investigation in the first year. Unfortunately, heavy equipment traffic increased near the study site because of a fire event during the first year. Therefore, for the second year, two more dunes near Fülöpháza were chosen for the study $\left(46^{\circ} 53^{\prime} 29^{\prime \prime} \mathrm{N}, 19^{\circ} 26^{\prime}\right.$ 35.6" E) with the same environmental characteristics (Fig. 1). On each selected dune, the NE and the SW facing sides (henceforth microsites) were chosen for collection of lichen material.

\section{Lichen material}

Lichen samples were collected in the Kiskunság region, Central Hungary, in the territory of Kiskunság National Park, to exclude the effect of human activity as much as possible. On both the SW and NE slopes of the dunes in the sampling area, the following species have been collected (from the association): the large, squamulose Cladonia foliacea (Huds.) Willd.; the fruticose Cladonia furcata (Huds.) Schrad., the cup lichens Cladonia magyarica Vain. and Cladonia pyxidata (L.) Hoffm.; and the crustose lichens Diploschistes muscorum (Scop.) R. Sant. and Thalloidima physaroides (Opiz) Opiz. Among others, these six lichen species are also members of the "Bunte Erdflechten-Gesellschaft" (Gams 1938), also known as the Fulgensietum fulgentis association, typical for this region (Büdel 2001). Thalli were collected from populations living on both the SW-and NE- 
Fig. 1 Location of the study sites in Hungary

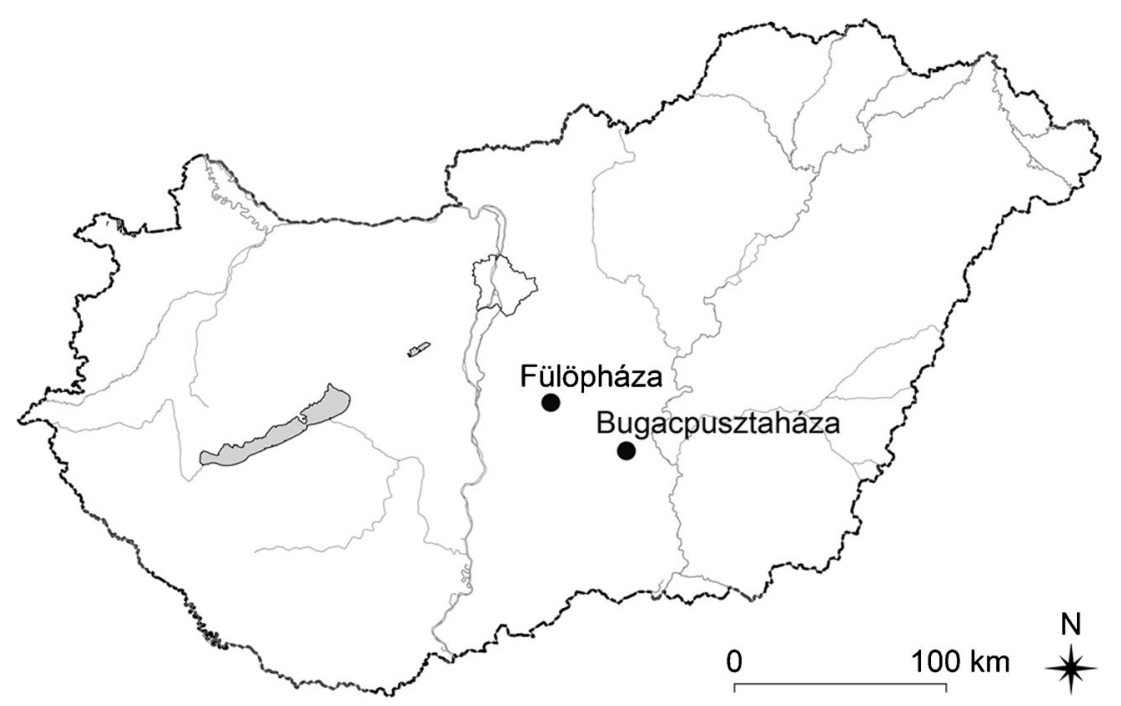

oriented microsites in 10 replicates per species, per aspect type, per microsite, in each of four seasons (Bugacpusztaháza: March, July and October of 2013, January of 2014; Fülöpháza: July and November of 2014, February and May of 2015) when possible. Altogether, almost 1200 specimens were measured during the investigation period. Due to the large number of the samples, specimens were collected at the same time, but measured later under nearly constant laboratory conditions. In the first year, some data are missing, especially from the summer period, because one of our investigation microsites was destroyed by heavy equipment/digger, and lichen thalli were challenging to find and collect. After sample collection, thalli were transported to the laboratory where they dried out under semi-natural conditions (i.e. seasonal temperature, humidity and light regime) (Csintalan et al. 1999). To avoid measuring the chlorophyll fluorescence of other photosynthesizing organisms living directly beside the lichen thalli, they were cleaned with special attention to these particles. Lichens were identified according to Smith et al. (2009), Verseghy (1994) and Wirth et al. (2013). A few days after collection, specimens were rehydrated by spraying with distilled water twice a day (in the morning and the afternoon) and kept under low light conditions (about $10 \mu \mathrm{mol} \mathrm{m} \mathrm{m}^{-2} \mathrm{~s}^{-1}$ ) at seasonal ambient temperature for 1-2 days, until the photosynthetic system regenerated (i.e. until $\mathrm{F}_{\mathrm{V}} / \mathrm{F}_{\mathrm{M}}$ became constant). In summer samples, this preparation process required more time (3 days) than for thalli collected in other seasons. After measurements were completed, voucher specimens were deposited in Lichen Herbarium VBI, Hungary.

\section{Chlorophyll $a$ fluorescence kinetic measurements}

Only healthy thalline lobes (without any sign of parasites or lichenicolous fungus) were selected for our studies.
Chlorophyll $a$ fluorescence kinetics were measured on fully water-saturated lichen thalli after 30 min of dark adaptation at room temperature $\left(\mathrm{T}=20-22{ }^{\circ} \mathrm{C}\right)$ using a portable pulse amplitude modulated fluorometer (FMS 2 Hansatech Instruments Ltd.; Modfluor software) as described in Jensen (2002). The maximum quantum yield of PSII photochemistry $\left(F_{V} / F_{M}\right)$, and Stern-Volmer non-photochemical quenching (NPQ), were calculated according to Kitajima and Butler (1975) and Bilger and Björkman (1990). These are the most frequently used chlorophyll fluorescence variables in ecological investigations. $\mathrm{F}_{\mathrm{V}} / \mathrm{F}_{\mathrm{M}}$ gives insight into the condition of the photosynthetic systems within the thalli, and shows how efficiently the photochemical reaction is proceeding. Similar to vascular plants, the photobiont algae of the lichen also protect themselves from the harmful effects of high light intensity, which cannot be used for photosynthesis (Demmig-Adams et al. 1989). The non-photochemical quenching represents the degree of these protective mechanisms (photoprotection) while photosynthesis is running.

\section{Micrometeorological data collection}

Two micrometeorological stations were placed at the Bugacpusztaháza site, on the opposite sides of a dune with $\mathrm{NE}$ and SW faces, in order to record changes of microclimate during the investigation period and to observe the main differences between the two microhabitat types. It was hypothesised that the conditions on the selected dune represent the prevailing conditions on other dunes of similar morphology and aspects found in the territory. For collecting micrometeorological data, two HOBO Micro Station H21-002 (Onset Computer Corporation, USA) were used with sensors of air temperature $\left(\mathrm{T}_{\text {air }}\right)$, relative humidity $(\mathrm{RH})$ and photosynthetically active radiation (PAR) at $0.5 \mathrm{~m}$ height, and soil temperature $\left(\mathrm{T}_{\text {soil }}\right)$ and soil water content $\left(\mathrm{WC}_{\text {soil }}\right)$ at $5 \mathrm{~cm}$ 
deep in the sand. Data were continuously recorded each minute. Vapour pressure deficit was calculated from measured data as follows: $\mathrm{VPD}=0.6108^{*} \exp .\left(17.27^{*} \mathrm{~T}_{\text {air }}\left({ }^{\circ} \mathrm{C}\right) /\left(\mathrm{T}_{\text {air }}\right.\right.$ $\left.\left.\left({ }^{\circ} \mathrm{C}\right)+237.3\right)\right) *(1-\mathrm{RH} / 100) * 10$. We also used meteorological and precipitation data derived from the meteorological station of Plant Ecology Research Group of Hungarian Academy of Sciences, Szent István University, which is located $4.2 \mathrm{~km}$ from the Bugacpusztaháza study site. The precipitation data were corrected by the locally recorded soil water content data. A meteorological station owned by the MTA Centre for Ecological Research, not far from the Fülöpháza sites $(1.3 \mathrm{~km})$, also recorded meteorological data. It provided information about environmental conditions and precipitation on the second study site. Micrometeorological data from the first spring are lacking, because data loggers were only installed after the first spring sampling. However, based on the spring data, recorded by the meteorological station of Plant Ecology Research Group, a rough estimation of environmental conditions before spring sampling was possible. Unfortunately, some micrometeorological data are missing because of an unexpected battery discharging, as well as damage to some wires by wild animals. Although a large amount of micrometeorological data were recorded, due to space restrictions, only the most relevant are presented here.

\section{Statistical analysis}

All statistical analyses were performed in the R statistical environment (R Core Team 2018). Sufficient sample size for a correct statistical comparison from the first year was available only for the $C$. pyxidata group and D. muscorum. The values of $F_{V} / F_{M}$ and NPQ fluorescence parameters (response variables) related to seasons and different microhabitat types (explanatory variables) were statistically evaluated by a linear model, followed by ANOVA to find differences between species. Because there were no significant differences in $\mathrm{F}_{\mathrm{V}} / \mathrm{F}_{\mathrm{M}}$ and NPQ between the microsites with the same direction within one site and one season, data were handled as one group, and therefore, each SW dataset was compared with each NE data within one site and one season for each species. The two (SW, NE aspect) and four (seasons) levels of the two explanatory variables $\left(\mathrm{F}_{\mathrm{V}} / \mathrm{F}_{\mathrm{M}}, \mathrm{NPQ}\right)$ generated eight groups according to the combination of variables at each site (Bugacpusztaháza, Fülöpháza), where each group was compared with each group. The differences between these groups were analysed by a multiple comparison Tukey-test on least square means by sites using the lsmeans package (Lenth 2016) in the $R$ environment ( $R$ Core Team 2018). The Shapiro-Wilk test was applied to test the normality of the samples, and a pairwise $t$ test was performed to compare the means of micrometeorological data, taking the average of every 10 min between the SW and NE facing sides of the investigated dune ( $\mathrm{R}$ Core Team 2018). In case of seasonal means, the average of the month preceding sample collection was taken using the dplyr package (Wickham et al. 2018). For creating figures, the $R$ environment was used.

\section{Results}

\section{Micrometeorological data}

Seasons The values of micrometeorological parameters usually differed not only among seasons but also among years (Table 1). The environmental variables observed from January 6, 2013 to January 6, 2015, showed clear seasonal patterns. During summers, the daily mean $\mathrm{T}_{\text {air }}$ was between 21 and $22{ }^{\circ} \mathrm{C}$ and $35-39.5^{\circ} \mathrm{C}$ maximum values were recorded; meanwhile, the daily mean RH was $67.1-70.2 \%$ depending on aspect. The mean PAR was $483-516 \mu \mathrm{mol} \mathrm{m}{ }^{-2} \mathrm{~s}^{-1}$, resulting in an average $23.6-26.6^{\circ} \mathrm{C}$ soil temperature and a 2$9 \%$ average daily soil water content depending on aspect. The daily mean VPD reached relatively high values between 10.4 $11.4 \mathrm{kPa}$. During the first summer, there were ten rainy days, with altogether $35.2 \mathrm{~mm}$ precipitation, with different intensities (light, intermediate, shower). In the second summer, the precipitation was $70.7 \mathrm{~mm}$ over ten rainy days, with varying intensity.

During autumns, $8.1-12{ }^{\circ} \mathrm{C}$ mean daily $\mathrm{T}_{\text {air }}$ was recorded, and the air temperature dropped below $0{ }^{\circ} \mathrm{C}$ on 5 (1st year) and 6 (2nd year) days in this season. The daily mean RH was higher than in the previous season, between 75.7-86.9\%, and the mean PAR was lower, $111-240 \mu \mathrm{mol} \mathrm{m}{ }^{-2} \mathrm{~s}^{-1}$. The mean daily $\mathrm{T}_{\text {soil }}$ was $8.8-15.8{ }^{\circ} \mathrm{C}$, and $3.9-10.6 \% \mathrm{WC}_{\text {soil }}$ was measured, depending on aspect. The daily mean vapour pressure deficit was 1.8-4.3 kPa. During the first autumn, there were 14 rainy days, with a total of $31.4 \mathrm{~mm}$ precipitation, with different intensities of the rain (light, intermediate). In the second autumn, the precipitation was $11.2 \mathrm{~mm}$ over seven rainy days, all as light rain.

The winters were cold, averaging $1.1-2.7{ }^{\circ} \mathrm{C} \mathrm{T}_{\text {air }}$, and 422 days were recorded, when the temperature dropped below $0{ }^{\circ} \mathrm{C}$ depending on year and aspect. The mean daily $\mathrm{RH}$ was relatively high during this season (81-88\%); meanwhile, the PAR remained relatively low $\left(59.8-86.8 \mu \mathrm{mol} \mathrm{m}{ }^{-2} \mathrm{~s}^{-1}\right)$, resulting in a moderate degree of soil warming (daily mean $\mathrm{T}_{\text {soil }}: 1.7-3.5^{\circ} \mathrm{C}$ ) depending on aspect. The water content of the soil was higher than recorded in summer and autumn, averaging 3.1-12.9\% according to year and direction. The daily mean VPD was $0.9-1.1 \mathrm{kPa}$ during winters. In the first winter, there were nine rainy/snowing days, with altogether $4.2 \mathrm{~mm}$ precipitation. During the second winter, the precipitation was $69.6 \mathrm{~mm}$ over 17 days.

In the first spring, the mean daily air temperature was $4.5{ }^{\circ} \mathrm{C}$; additionally, $81.8 \%$ mean $\mathrm{RH}, 161 \mu \mathrm{mol} \mathrm{m}{ }^{-2} \mathrm{~s}^{-1}$ 
Table 1 The average values of $\mathrm{T}_{\text {air }}, \mathrm{RH}, \mathrm{VPD}, \mathrm{PAR}, \mathrm{T}_{\text {soil }}, \mathrm{WC}_{\text {soil }}$ and precipitation recorded in different seasons during a 2-year investigation period measured on the south-west (SW) and north-east (NE) facing microhabitats located on a dune. Mean of differences between SW and
NE facing slopes in the present micrometeorological parameters during the whole measuring period is also presented. *Differences significant between SW and NE facing dune side (pairwise $t$ test, $p<0.05$ )

\begin{tabular}{|c|c|c|c|c|c|c|c|}
\hline Direction/season & $\mathrm{T}_{\text {air }}\left({ }^{\circ} \mathrm{C}\right)$ & $\mathrm{RH}(\%)$ & $\mathrm{VPD}(\mathrm{kPa})$ & $\operatorname{PAR}\left(\mu \mathrm{mol} \mathrm{m} \mathrm{m}^{-2} \mathrm{~s}^{-1}\right)$ & $\mathrm{T}_{\text {soil }}\left({ }^{\circ} \mathrm{C}\right)$ & $\mathrm{WC}_{\text {soil }}(\%)$ & Precipitation $(\mathrm{mm})$ \\
\hline \multicolumn{8}{|l|}{ First year } \\
\hline Spring $_{1)}$ & 4.46 & 81.1 & 1.6 & 161 & 5.3 & NA & 78.4 \\
\hline Summer NE & 21.7 & 70.2 & 11.2 & 516 & 24.4 & 8 & 35.2 \\
\hline Summer SW & 21.8 & 69.9 & 11.4 & 527 & 26.6 & 2 & \\
\hline Autumn NE & 12 & 76.1 & 4.2 & 240 & 13.7 & 10.6 & 31.4 \\
\hline Autumn SW & 12.3 & 75.7 & 4.3 & 263 & 15.8 & 4.2 & \\
\hline Winter NE & 2.6 & 88.1 & 1.1 & 59.8 & 2.8 & 9.7 & 4.2 \\
\hline Winter SW & 2.7 & 88.4 & 1 & 66.8 & 3.5 & 3.1 & \\
\hline \multicolumn{8}{|l|}{ Second year } \\
\hline Spring NE & 16.4 & 73.9 & 6.6 & 401 & 17.7 & 9.2 & 58 \\
\hline Spring SW & 16.5 & 73.2 & 6.7 & 363 & 20.5 & 3.4 & \\
\hline Summer NE & 20.9 & 67.7 & 10.4 & 483 & 23.6 & 9 & 70.7 \\
\hline Summer SW & 20.9 & 67.1 & 10.5 & 494 & 25.8 & 2.8 & \\
\hline Autumn NE & 8.1 & 86.6 & 1.8 & 111 & 8.8 & 10.3 & 11.2 \\
\hline Autumn SW & 8.2 & 86.9 & 1.8 & 121 & 10 & 3.9 & \\
\hline Winter NE & 2.4 & 86.5 & 1.1 & 76.8 & 1.7 & 12.9 & 69.6 \\
\hline Winter SW & 1.1 & 88 & 0.9 & 86.8 & 2.6 & 3.4 & \\
\hline Mean of the differences & $0.171^{*}$ & $-0.494 *$ & $0.169^{*}$ & $14.089^{*}$ & $2.047^{*}$ & $-6.28^{*}$ & \\
\hline
\end{tabular}

$\mathrm{T}_{\text {air }}$, air temperature; $\mathrm{RH}$, relative humidity; $\mathrm{VPD}$, vapour pressure deficit; $\mathrm{PAR}$, photosynthetically active radiation; $\mathrm{T}_{\text {soil }}$, soil temperature; $\mathrm{WC}_{\text {soil }}$, soil water content

${ }_{1)}$ Meteorological data from the meteorological station of the Plant Ecology Research Group of Hungarian Academy of Sciences, Szent István University near the investigation site

PAR and $1.6 \mathrm{kPa}$ VPD were recorded. The daily mean $\mathrm{T}_{\text {soil }}$ was $5.3^{\circ} \mathrm{C}$. During the first spring, there were 19 rainy days, with altogether $78.4 \mathrm{~mm}$ precipitation. In the second spring, the mean daily $\mathrm{T}_{\text {air }}$ was around $16.5^{\circ} \mathrm{C}$, although on 1 day, the temperature dropped below $0{ }^{\circ} \mathrm{C}$. The daily mean $\mathrm{RH}$ was between 73.2 and $79.9 \%$; meanwhile, the mean PAR was 363 and $401 \mu \mathrm{mol} \mathrm{m} \mathrm{s}^{-1}$, resulting in 17.7 and $20.5^{\circ} \mathrm{C}$ daily mean $\mathrm{T}_{\text {soil }}$ and $3.4 \%$ and $9.2 \% \mathrm{WC}_{\text {soil }}$ depending on aspect. The daily mean VPD was $6.6 \mathrm{kPa}(\mathrm{NE})$ and $6.7 \mathrm{kPa}(\mathrm{SW})$. In the second spring, the precipitation was $58 \mathrm{~mm}$ over 16 days with different rain intensities.

Aspect The application of pairwise $t$ test showed that the means of micrometeorological data between the SW and $\mathrm{NE}$ facing sides of the investigated dune were significantly different for every parameter during the 2-year measuring period (Table 1). The $\mathrm{T}_{\text {air }}$, PAR (corrected with slope and orientation according to Olmo et al. 1999), $\mathrm{T}_{\text {soil }}$ and VPD values were significantly higher $(p<0.001)$ on the $\mathrm{SW}$ than on the NE oriented side, where the RH and $\mathrm{WC}_{\text {soil }}$ proved to be significantly higher $(p<0.001)$ at 95\% confidence (Table 1). The most remarkable differences among the SW and NE sides were observed in $\mathrm{T}_{\text {soil }}$ (mean $60 \%$ higher on SW slope) and in $\mathrm{WC}_{\text {soil }}$ (mean
$75 \%$ higher on NE slope). The daily fluctuation of differences for every micrometeorological parameter changed seasonally. The higher daily fluctuation was observed in summer, whereas on winter days, a more balanced difference in light and humidity conditions was detected (except $\mathrm{WC}_{\text {soil }}$, where the difference between the two microhabitat types was close to constant over each year) (Fig. 2a-f). According to the results, the microhabitats situated on the SW sides of the dunes can be characterised as arid, whereas the NE-oriented sides as less arid. Figure 2 shows the differences between the SW and NE facing dune sides in micrometeorological parameters changing during the day in different seasons (row data). The false colour scale indicates the degree and direction of difference between SW and NE facing dune sites. Red indicates that the value of the given parameter is higher on the SW than on the NE side, whereas the blue colour indicates that the value is lower on the SW than on the NE side. For example, the $T_{\text {soil }}$ is higher on the NE than on the SW side of the dune in summer mornings. Then, in the afternoon, the $\mathrm{T}_{\text {soil }}$ was higher on the $\mathrm{SW}$ than on the opposite side of the dune. Interestingly, in winter, the difference between the $\mathrm{SW}$ and the NE side in $\mathrm{T}_{\text {soil }}$ is nearly constant during the day. 

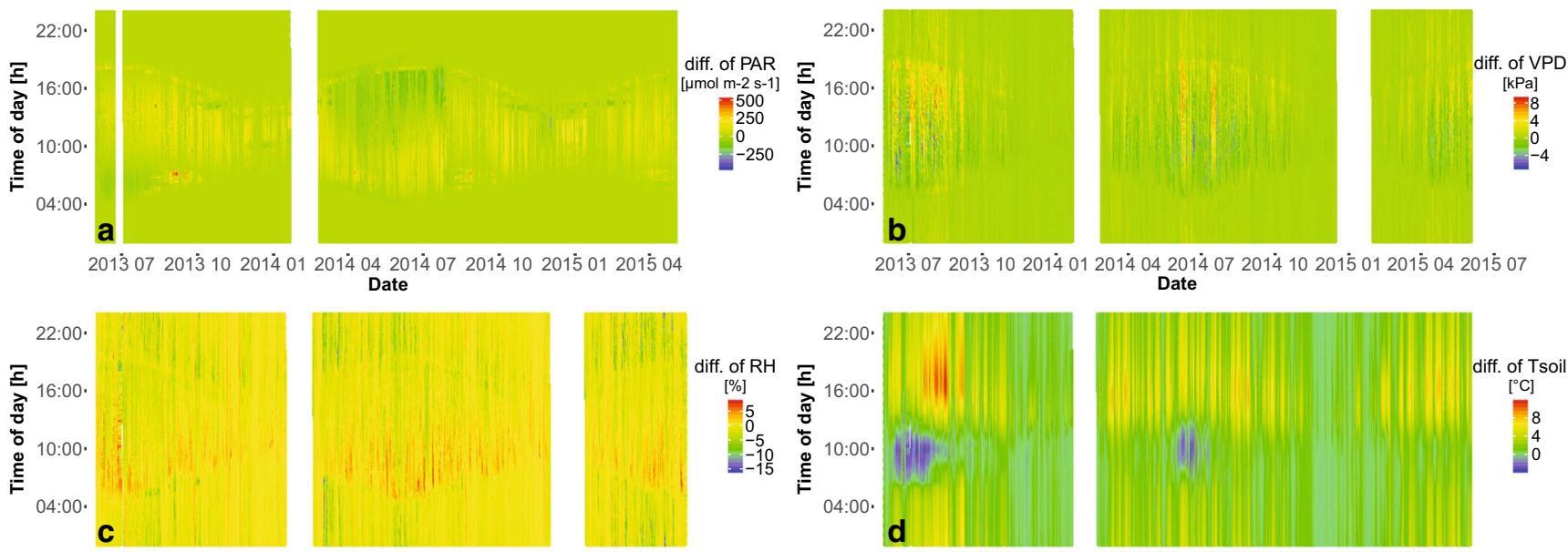

$2013 \dot{3} 07201310201 \dot{4} 012014 \ddot{4} 04201 \dot{4} 072014102015012015042015 \dot{5} 07$ Date
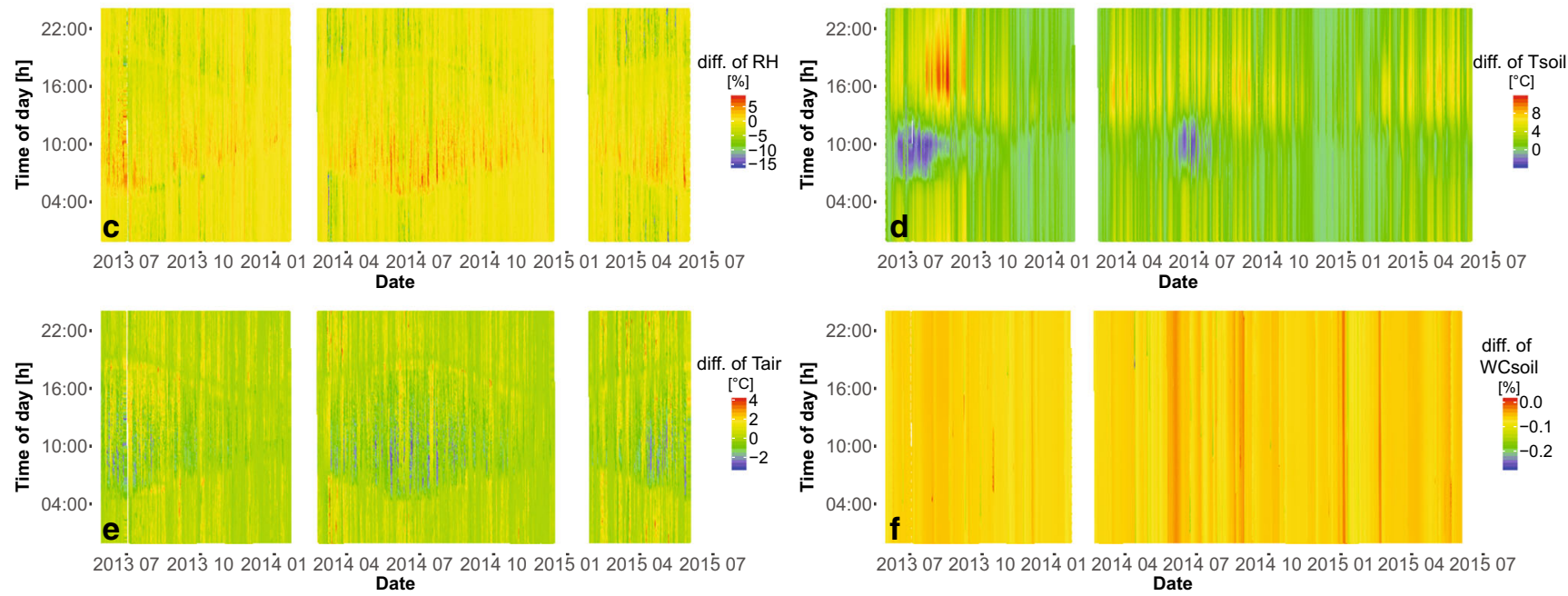

Date

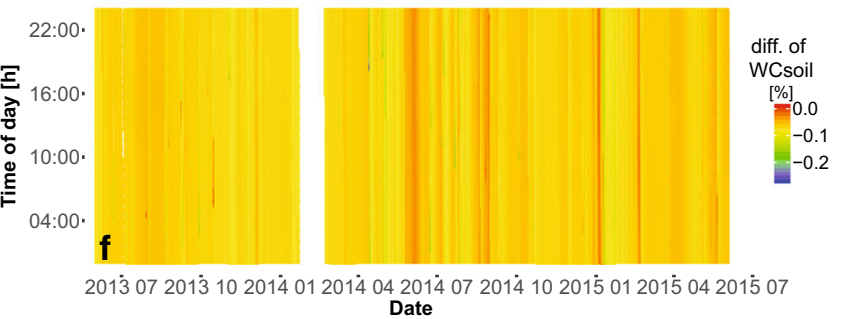

Fig. 2 a-f The extent and direction of difference between SW and NE side of a dune in micrometeorological parameters during days in different seasons (row data). During the 2-year investigation period, scale (01. 06. 2013-01. 06. 2015) PAR (a), VPD (b), RH (c), $\mathrm{T}_{\text {soil }}(\mathbf{d}), \mathrm{T}_{\text {air }}(\mathbf{e})$ and $\mathrm{WC}_{\text {soil }}(\mathbf{f})$ are depicted. The Y-axis represents the time within a day (the

\section{Chlorophyll $a$ fluorescence parameters}

\section{The maximum quantum yield of photosystem II photochemistry $\left(\mathrm{F}_{\mathrm{V}} / \mathrm{F}_{\mathrm{M}}\right)$}

Since we could not observe any significant differences $\left(\mathrm{F}_{\mathrm{V}} / \mathrm{F}_{\mathrm{M}}\right.$ $p=0.576$; NPQ $p=0.902$ ) in the physiological properties of the morphologically very similar $C$. magyarica and C. pyxidata (both represent the same growth form), we grouped them together as the "C. pyxidata group."

For all five different terricolous lichen species/species groups investigated, both seasonality and aspect had an effect on $\mathrm{F}_{\mathrm{V}} / \mathrm{F}_{\mathrm{M}}(p<0.001)$, as well as on NPQ (1st year season: $p<0.001$, aspect: $p=0.006$; 2 nd year $p<0.001$ for both season and aspect), each year (Figs. 3 and 4).

In the $C$. pyxidata group, the average of $\mathrm{F}_{\mathrm{V}} / \mathrm{F}_{\mathrm{M}}$ was higher in $\mathrm{NE}$ than in SW-exposed thalli; however, the difference was significant only in autumn and winter (Fig. 3a, e). Regarding seasons, spring samples showed significantly higher values than winter ones on NE facing microhabitats, and winter and autumn ones in SW facing microhabitats. Meanwhile, in the second year on SW facing microsites, this value is significantly higher in spring samples than in samples from other seasons. On NE facing microsites, autumn and spring samples showed significantly higher values than summer ones. The $\mathrm{F}_{\mathrm{V}} / \mathrm{F}_{\mathrm{M}}$ was usually higher

hours of the day), meanwhile the $\mathrm{X}$-axis the time within 2 years by date (months). The false colour scale indicates the degree and direction of difference between SW and NE facing dune sites. Red colour indicates higher values on the SW than on the NE side, meanwhile blue colour signs lower value on the SW than on the NE side

in NE than in SW-exposed thalli in D. muscorum; however, the differences were not significant (Fig. 3b, f). Neither the seasonal fluctuation of $\mathrm{F}_{\mathrm{V}} / \mathrm{F}_{\mathrm{M}}$ was remarkable in this species. Significantly, higher $F_{V} / F_{M}$ was measured in the NE than in the SW populations of $C$. foliacea in summer and autumn. In contrast, in winter and spring, this value did not differ significantly among microhabitats (Fig. 3c). In summer, considerably lower values were recorded than in other seasons on SW facing microhabitats. Still, it showed a slightly different picture on NE facing microhabitats: significantly higher $\mathrm{F}_{\mathrm{V}} / \mathrm{F}_{\mathrm{M}}$ was measured in autumn and spring than in summer and winter. Significantly, higher $\mathrm{F}_{\mathrm{V}} / \mathrm{F}_{\mathrm{M}}$ was found in NE than in SW-exposed thalli of C. furcata in every season, except in spring (Fig. 3d). For both types of microhabitat, significantly lower values were measured in summer than in other seasons. The NE populations of T. physaroides did not usually show significantly higher $\mathrm{F}_{\mathrm{V}} / \mathrm{F}_{\mathrm{M}}$ values than thalli of SW populations, only in winter (Fig. $3 \mathrm{~g}$ ). The fluctuation of $\mathrm{F}_{\mathrm{V}} / \mathrm{F}_{\mathrm{M}}$ between seasons, however, was markedly higher in SW than in NE exposed thalli. On SW facing microhabitats, significantly higher values were measured in spring and autumn samples than in summer or winter ones, but there were no significant differences detected on NE sides between seasons in this parameter.

In general, a significant (1st year: $p=0.036$, 2nd year: $p<0.001)$ difference was detected among species in both 

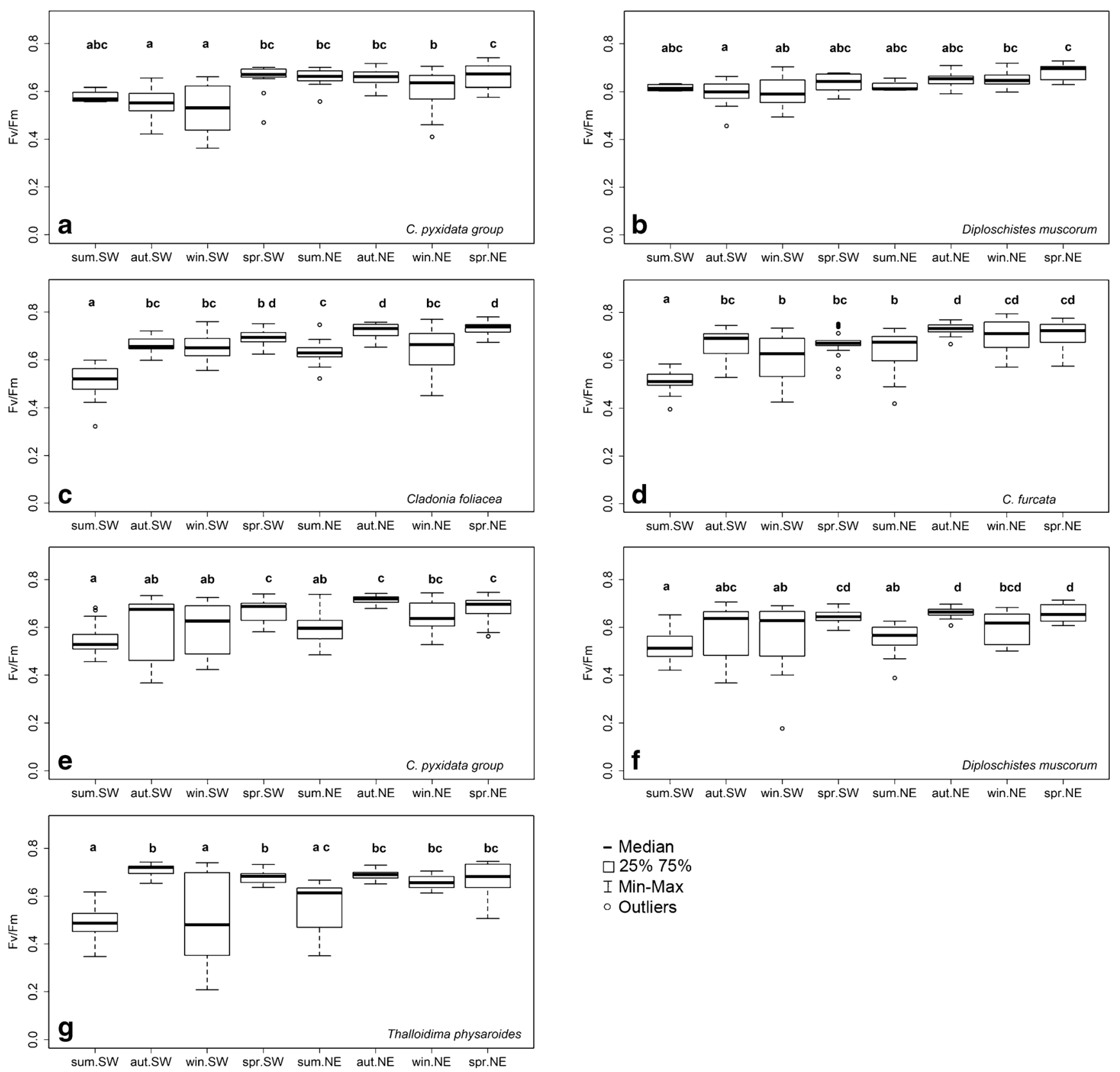

Fig. 3 a-g Variation in $F_{V} / F_{M}$ (relative unit) within terricolous lichen species/species group living both on SW and on NE facing microhabitats in different seasons (spr, spring; sum, summer; aut, autumn; win, winter) during the 2-year investigation period. From the first year, only values of the Cladonia pyxidata group (a) and Diploschistes muscorum (b) are presented. In the second year, data of Cladonia foliacea (c), C. furcata

years. The thalli of large squamulose and fruticose species (C. foliacea, C. furcata) showed higher $\mathrm{F}_{\mathrm{V}} / \mathrm{F}_{\mathrm{M}}$ than those measured in crustose species (D. muscorum, T. physaroides). Meanwhile, within the same growth form, there were no remarkable interspecific differences in this parameter. C. pyxidata showed transitional $\mathrm{F}_{\mathrm{V}} / \mathrm{F}_{\mathrm{M}}$ values between those two groups.

(d), the C. pyxidata group (e), Diploschistes muscorum (f) and Thalloidima physaroides (g) are presented. Within one year and species/species group, each group was compared with each group by a multiple comparison Tukey-test on least square means by sites. Means with the same letter are not significantly different at $95 \%$ confidence

\section{Non-photochemical quenching}

There were significant differences between the NE and SW populations in non-photochemical quenching (NPQ) values, mostly in the second year in the case of the C. pyxidata group (Fig. 4e). The values of NPQ were significantly higher in NE than in SW-exposed thalli in summer, winter and autumn. In 

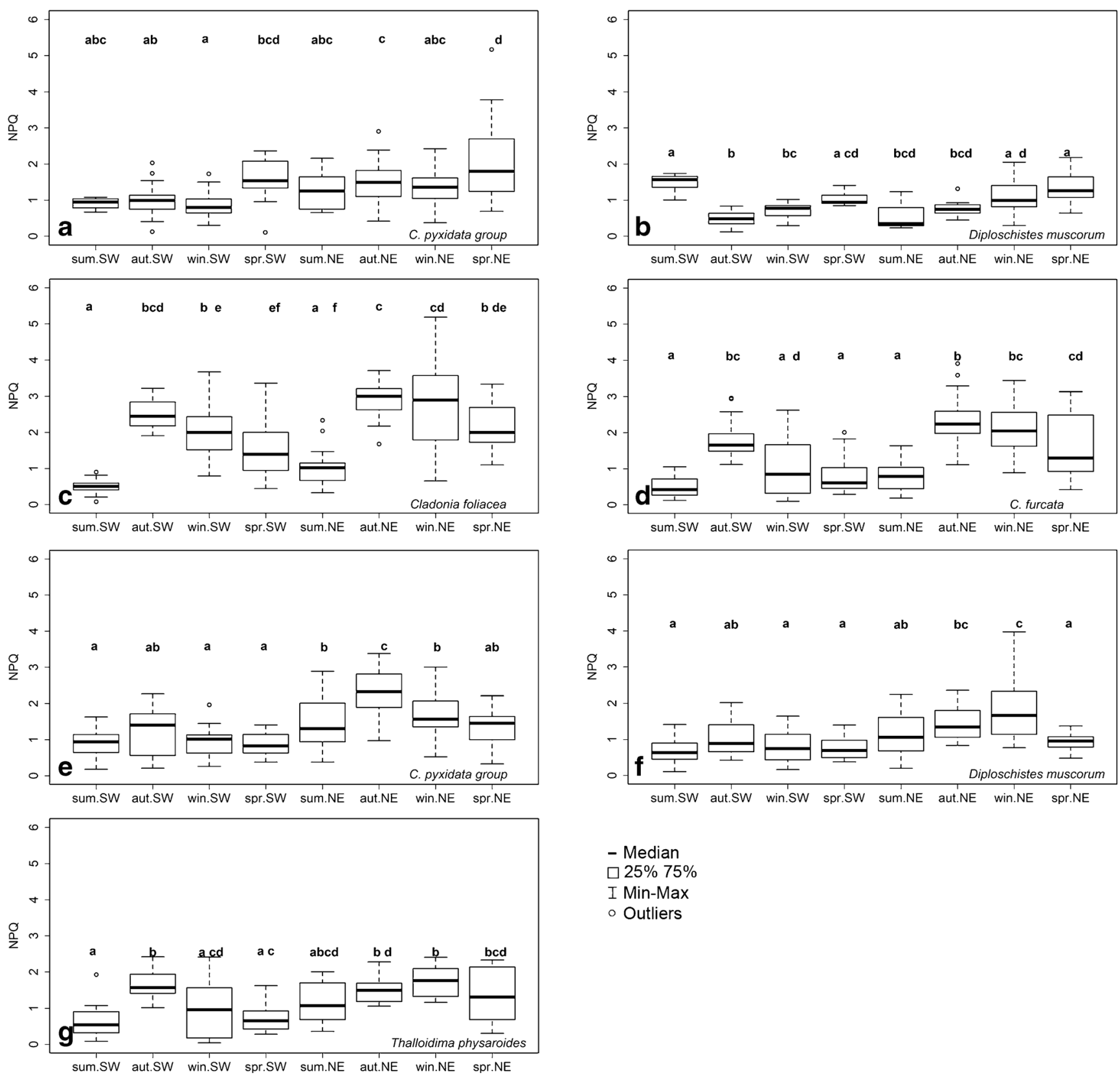

Fig. 4 a-g Variation in NPQ (relative unit) within terricolous lichen species living both on microhabitats with $\mathrm{SW}$ and NE aspects in different seasons (spr, spring; sum, summer; aut, autumn; win, winter) during the 2-year investigation period. From the first year, only data of the Cladonia pyxidata group (a) and Diploschistes muscorum (b) are presented. In the second year, data of $C$. foliacea (c), C. furcata (d), the

the first year, the NPQ was significantly higher in spring samples than in winter samples in SW facing microhabitats; meanwhile, in NE-exposed thalli, the spring samples showed significantly higher NPQ values than those measured in other seasons (Fig. 4a). In the second year, there was no remarkable difference between seasons on SW facing microsites; however, on microsites with opposite aspect, significantly higher values were measured in autumn samples than in other

C. pyxidata group (e), Diploschistes muscorum (f) and Thalloidima physaroides (g) are presented. Within 1 year and species/species group, each group was compared with each group by a multiple comparison Tukey-test on least square means by sites. Means with the same letter are not significantly different at $95 \%$ confidence

seasons (Fig. 4e). Higher NPQ was usually measured in NE compared with SW-exposed thalli of D. muscorum; however, the difference was significant only in the summer and winter in the first year (Fig. 4b), and winter in the second year (Fig. 4f). The seasonal fluctuation was more remarkable in the first year in both type of microhabitats; however, in the second year, a significant difference between seasons was detected only in thalli of NE facing populations. Higher NPQ was 
measured in the NE than in the SW populations of $C$. foliacea, although this difference was significant only in winter (Fig. $4 c)$. Significantly, higher NPQ was measured in autumn than in summer, or in spring on both types of microhabitats; additionally, NE populations showed significantly lower values in summer than in other seasons. However, higher NPQ was measured in the NE than in the SW populations of C. furcata in every season; it was more pronounced in winter and spring (Fig. 4d). It was true for both NE and SW populations that in autumn samples, significantly higher NPQ was recorded than in summer or spring. The NE-exposed thalli of T. physaroides usually did not show significantly higher NPQ values than thalli of SW facing microsites, except in the winter (Fig. 4g). There was no significant difference between seasons in NE populations; meanwhile, significantly higher values were measured in autumn than in other seasons in SW populations.

Significantly, higher $(p<0.001)$ NPQ was measured in $C$. foliacea than in other investigated species. Specimens of T. physaroides, D. muscorum and the C. pyxidata group showed moderate changes among seasons in this parameter compared with $C$. foliacea and $C$. furcata, especially for SW facing populations (Fig. 4).

\section{Discussion}

\section{The maximum quantum yield of photosystem II photochemistry $\left(F_{V} / F_{M}\right)$}

The effect of microhabitat conditions The results clearly indicate that $\mathrm{F}_{\mathrm{V}} / \mathrm{F}_{\mathrm{M}}$ is usually higher on less arid than on arid microhabitats for each species studied. The results also show a remarkable species-specific seasonality. From a micrometeorological point of view, there was an unambiguous contrast between arid and less arid microsites. The most remarkable difference was observed in soil temperature, which was higher for SW than for NE facing sides during the daytime (Fig. 2), indicating a higher amount of incoming solar radiation on SW than on NE-oriented microsites. Additionally, higher soil water content and lower VPD on NE compared with SW side provided a higher amount of humidity for rehydration/ activation for terricolous lichens. The shading effect of vascular plants is an additional factor influencing light and humidity conditions, which can generate a higher $\mathrm{F}_{\mathrm{V}} / \mathrm{F}_{\mathrm{M}}$ value in lichens (Kalapos and Mázsa 2001; Serpe et al. 2013). On less arid microsites, both the cover and average height of vascular plants were higher than on arid ones (NE: $14 \%$ cover, $6 \mathrm{~cm}$ height; SW: $8 \%$ cover, $2.5 \mathrm{~cm}$ height, (Veres et al. unpublished data)). As previously revealed for epiphytic lichen species (e.g. Atala et al. 2015; Gauslaa et al. 2006; Pirintsos et al. 2011), there is a more remarkable, long-term reduction in $\mathrm{F}_{\mathrm{V}} / \mathrm{F}_{\mathrm{M}}$ in lichens living in sunny, open places compared with shade populations. This also explains the lower measured $\mathrm{F}_{\mathrm{V}} /$ $F_{M}$ values in the present study.

The effect of seasonal changes The seasonal changes also had a characteristic effect on photosynthetic activity. In general, similar to previous studies (MacKenzie et al. 2002; Vráblíková et al. 2006), higher $\mathrm{F}_{\mathrm{V}} / \mathrm{F}_{\mathrm{M}}$ values were detected in spring and autumn samples compared with summer and winter ones in both types of microhabitats. This result indicates that the environmental conditions during spring and autumn were more favourable from a photosynthetic point of view than in the other two seasons. High relative humidity and also increasing intensity of incident light were representative for spring and autumn. During winter and summer, the investigated species showed lower $\mathrm{F}_{\mathrm{V}} / \mathrm{F}_{\mathrm{M}}$ values, indicating that lichen thalli had been exposed to stress (Maxwell and Johnson 2000). In summer, it could be explained by heat and by light stress, which had a photoinhibition effect on lichen thalli both separately and combined (Gauslaa and Solhaug 1999). The daily average PAR and VPD were relatively high, creating a challenging environment for lichens in the summer. The second-lowest $\mathrm{F}_{\mathrm{V}} / \mathrm{F}_{\mathrm{M}}$ values were usually measured in winter samples. In this season, the low temperature, days below freezing (4-22 during the present study), and thick snow coverage could have an inhibitory effect on metabolic activity and photosynthesis in lichens (Leisner et al. 1996; Schroeter et al. 2011). According to Hájek et al. (2009, 2016), $\mathrm{F}_{\mathrm{V}} / \mathrm{F}_{\mathrm{M}}$ is a cold-sensitive parameter, which shows a species-specific decrease during declining temperature, confirming the findings of the present study.

The species-specific response Comparing the different species, the $\mathrm{F}_{\mathrm{V}} / \mathrm{F}_{\mathrm{M}}$ was usually higher in the large, squamulose $C$. foliacea and fruticose C. furcata than in the other two, crustose species, D. muscorum and T. physaroides for every season in the second year. Meanwhile, the thalli of the C. pyxidata group showed transitional values between the two abovementioned groups.

The former two groups differ from each other mainly in their photosynthetic partners (Beck et al. 2002; Friedl 1987; Smith et al. 2009; Timdal 1991; Wedin et al. 2015), which probably could explain the differences in $\mathrm{F}_{\mathrm{V}} / \mathrm{F}_{\mathrm{M}}$ values (Demmig-Adams et al. 1990). Their different morphology could also explain the variability in $\mathrm{F}_{\mathrm{V}} / \mathrm{F}_{\mathrm{M}}$ between growth forms due to water household (Lange and Green 2003). The thalli of the $C$. foliacea and $C$. furcata have a higher surface area to volume ratio; have loose, less compact thalli; and live higher above the ground than those of the $C$. pyxidata group, D. muscorum or T. physaroides. The latter species usually live on moss cushions, ensuring more humid micro-conditions than lichens living on bare soil (Colesie et al. 2012). Because of these reasons, the air ventilation and boundary layer, radiation and temperature could have a more 
substantial influence on the water household of $C$. foliacea and $C$. furcata thalli than on the $C$. pyxidata group, $D$. muscorum or on T. physaroides under the same atmospheric humidity conditions. Lange and Green (2003) revealed a species-specific duration of metabolic activity depending on the thallus growth form. It was also shown that C. foliacea could activate rapidly even between different humidity conditions, represented here by the different seasons. Lichens could utilize dew and heavy rain showers during summer (Veste et al. 2001), or high and frequently saturated air humidity, dew, fog and rain in spring and autumn, as a water source (e. g. Lange and Green 2003), as well as melting snow and frost in winter (e.g. Colesie et al. 2016; Schlensog et al. 2013). All investigated species vary considerably in seasonal fluctuation of their average $\mathrm{F}_{\mathrm{V}} / \mathrm{F}_{\mathrm{M}}$ values; however, this fluctuation is more pronounced in C. foliacea, C. furcata and T. physaroides than in the C. pyxidata group or in D. muscorum because of the abovementioned possible reasons.

The combined effect of microhabitat and seasonal changes Regarding seasonality, the most significant difference in $\mathrm{F}_{\mathrm{V}} / \mathrm{F}_{\mathrm{M}}$ between $\mathrm{SW}$ and NE populations of $C$. foliacea and $C$. furcata appeared in the summer season. The microhabitat conditions (radiation, humidity) probably had a more pronounced effect on the water household of these species. Because of fruticose habit and thin cortical layer (C. furcata) (Verseghy 1971), or the lack of lower cortical layer (C. foliacea), the thalli of these two species presumably dry out more rapidly on arid than on less arid microhabitats compared with other investigated species. D. muscorum is able to begin photosynthetic activity even at low water content (Lange et al. 1997), which can explain why this species did not show any significant difference between sun and shade populations in summer.

\section{Non-photochemical quenching}

The effect of microhabitat conditions Our results suggest that non-photochemical quenching (NPQ) is usually higher on shaded than on exposed microhabitats in the different investigated lichen species. One possible explanation of this apparent paradox phenomenon is that populations living on NE oriented slopes are exposed to wet conditions in the early morning time, and light can reach their surface more intensely than those growing on the opposite, SW facing slopes. The wet lichen thallus is more translucent; therefore, the photosynthetic apparatus needs more protection against the harmful excess light energy than in dried thalli (Heber et al. 2006), where most of the radiation is reflected from the surface of the thallus (Ertl 1951).
The effect of seasonal changes The seasonal fluctuation of NPQ was usually more pronounced on less arid than on arid microsites. In autumn and winter, higher humidity and incoming light were typical. Under these conditions (prolonged moistened active periods and solar radiation), wet lichen thalli needed more protection against harmful excess light energy, resulting in higher NPQ (Barták et al. 2000). In addition to other factors, more frequent desiccation-hydration cycles might increase the NPQ values in these seasons (Vráblíková et al. 2006). Seasonal differences in NPQ have also been found in other lichen species, for example, Xanthoria parietina (Gauslaa and McEvoy 2005; Vráblíková et al. 2006).

The species-specific response Our results also show a clear species-specific seasonality of NPQ. The highest values were measured among species of the $C$. pyxidata group in summer. This could be explained by the fact that these species are usually growing on moss thalli, ensuring prolonged hydration during dry days (Colesie et al. 2012). However, these lichens are even more threatened by the intensive radiation, and are unable to protect themselves due to desiccation-induced defence mechanisms (Heber et al. 2006; Kranner et al. 2008). Therefore, wet thalli needed more protection against harmful excess light energy by increasing NPQ. Favourable humidity conditions (lower VPD), as well as irradiation, could result in the higher NPQ values in autumn (e.g. C. foliacea) than those measured in summer (e.g. C. foliacea). In winter time, a species-specific response to cold (e.g. C. foliacea; the C. pyxidata group) was detected; this was also observed by Mishra and co-workers (Mishra et al. 2015), who found that NPQ values decreased simultaneously with decreasing temperatures.

The seasonal fluctuation of NPQ was different in the investigated species. It was notable in C. foliacea and C. furcata, but less remarkable in the C. pyxidata group, or D. muscorum. This finding could be explained by the thin (or absent) cortical layer on the lower side of the thallus in the former two species, causing lower water household capacity, but also by the higher amount of incoming light reaching the photobiont cells. Samples of T. physaroides also showed moderate changes in NPQ among seasons compared with Cladonia species. The NPQ values of D. muscorum differed among seasons, and also among microhabitats and years, indicating relatively rapid adaptation ability of this species to changing light conditions. The highest NPQ values were usually observed in C. foliacea thalli. The reason for this phenomenon could be that because of the thinner gonidial layer (Verseghy 1971), the self-shading effect of photobiont cells could be lower, compared with the other investigated Cladonia species (Wu et al. 2014), which could result in an increased photoprotective mechanism in the hydrated state. Additionally, because of the thin cortical layer, a more frequent desiccation-hydration 
period could also increase the level of NPQ (Vráblíková et al. 2006). Lower values of NPQ found in the other investigated species probably indicate that other protection mechanisms are also working in the background. These species-specific responses could be, e.g. the light-reflecting white colour of the thallus (D. muscorum); thick cortical layer (e.g. Beckett et al. 2008; Gauslaa et al. 2017; Váczi et al. 2018); hairiness (Bianchi et al. 2019b); production of UV-reflective lichen substances (e.g. usnic acid, fumarprotocetraric acid in C. foliacea); light-reflecting calcium oxalate crystals (T. physaroides); or biochemical protective mechanisms (Gasulla et al. 2018).

Conclusion In this extensive study, we investigated the effect of microhabitat conditions and seasonal changes on photosynthetic functioning simultaneously in five terricolous lichen species/species groups (representing different growth forms). These effects have not widely studied before. Therefore, our results provide new information on how these species can adapt to varying conditions with regard to photosynthetic activity and photoprotection. Directional aspect had a speciesspecific effect on seasonal photosynthetic function due to different light and humidity conditions. The different values of $\mathrm{F}_{\mathrm{V}} / \mathrm{F}_{\mathrm{M}}$ and NPQ of the five lichen species/species groups under the same humidity and light conditions can be explained by their different morphologies, and thus their water household capacity, photobiont or lichen substances. We suggest future workers study more than one species to investigate the response of lichens to changing environmental conditions in space and/or in time. Additionally, because both photosynthetic activity, and a part of photoprotection, derive from the algal cells in lichens, future work should focus on speciesspecific differences of chlorophyll fluorescence in the different chlorobiont partners found in lichens (e.g. Asterochloris, Trebouxia).

Acknowledgements The authors would like to thank Anita Juhász and Zoltán Zsíros for the help with fieldwork and Melinda Lajkó for technical assistance. We also thank the contribution of György Kröel-Dulay, Gábor Ónodi and Krisztina Pintér to meteorological data and Viktor Szigeti for the help with statistical analysis. We would like to express our thanks to the Kiskunság National Park for permission to conduct research on the territory; and to Bence Kovács, Zsanett Laufer, Evelin Péli and Viola Pomozi for useful comments. We are very grateful to Scott LaGreca for the revision of the English text.

Funding information Open access funding provided by Centre for Ecological Research. This work was supported by the Hungarian Scientific Research Fund OTKA-T101713 and the National Research Development and Innovation Fund NKFI K 124341.

Open Access This article is licensed under a Creative Commons Attribution 4.0 International License, which permits use, sharing, adaptation, distribution and reproduction in any medium or format, as long as you give appropriate credit to the original author(s) and the source, provide a link to the Creative Commons licence, and indicate if changes were made. The images or other third party material in this article are included in the article's Creative Commons licence, unless indicated otherwise in a credit line to the material. If material is not included in the article's Creative Commons licence and your intended use is not permitted by statutory regulation or exceeds the permitted use, you will need to obtain permission directly from the copyright holder. To view a copy of this licence, visit http://creativecommons.org/licenses/by/4.0/.

\section{References}

Armstrong RA (2017) Adaptation of lichens to extreme conditions. In: Shukla V, Kumar S, Kumar N (eds) Plant adaptation strategies in changing environment. Springer Nature, Singapore, pp 1-27. https://doi.org/10.1007/978-981-10-6744-0 1

Atala C, Schneider C, Bravo G, Quilodrán M, Vargas R (2015) Anatomical, physiological and chemical differences between populations of Pseudocyphellaria. Gayana Bot 72(1):21-26. https://doi. org/10.4067/S0717-66432015000100003

Barták M, Hájek J, Gloser J (2000) Heterogeneity of chlorophyll fluorescence over thalli of several foliose macrolichens exposed to adverse environmental factors: interspecific differences as related to thallus hydration and high irradiance. Photosynthetica 38(4):531-537. https://doi.org/10.1023/A:1012405306648

Baruffo L, Tretiach M (2007) Seasonal variations of Fo, Fm and Fv/Fm in an epiphytic population of the lichen Punctelia subrudecta (Nyl.) Krog. Lichenologist 39(6):555-565. https://doi.org/10.1017/ S0024282907006846

Beck A, Kasalicky T, Rambold G (2002) Myco-photobiontal selection in a Mediterranean cryptogam community with Fulgensia fulgida. New Phytol 153:317-326. https://doi.org/10.1046/j.0028-646X. 2001.00315.x

Beckett RP, Kranner I, Minibayeva FV (2008) Stress physiology and the symbiosis. In: Nash THIII (ed) Lichen biology, 2nd edn. Cambridge University Press, Cambridge, pp 134-151. https://doi.org/10.1017/ CBO9780511790478.009

Belnap J, Lange OL (eds) (2003) Biological soil crusts: structure, function, and management, 1st edn. Berlin Heidelberg, Springer-Verlag

Bianchi E, Paoli L, Colzi I, Coppi A, Gonnelli C, Lazzaro L, Loppi S, Papini A, Vannini A, Benesperi R (2019a) High-light stress in wet and dry thalli of the endangered Mediterranean lichen Seirophora villosa (Ach.) Frödén: does size matter? Mycol Prog 18:463-470. https://doi.org/10.1007/s11557-018-1451-0

Bianchi E, Benesperi R, Colzi I, Coppi A, Lazzaro L, Paoli L, Papini A, Pignattelli S, Tani C, Vignolinie P, Gonnelli C (2019b) The multipurpose role of hairiness in the lichens of coastal environments: insights from Seirophora villosa (Ach.) Frödén. Plant Physiol. Biochem. 141:398-406. https://doi.org/10.1016/j.plaphy.2019.06. 022

Bilger W, Björkman O (1990) Role of the xanthophyll cycle in photoprotection elucidated by measurements of light-induced absorbance changes, fluorescence and photosynthesis in leaves of Hedera canariensis. Photosynth Res 25:173-185. https://doi.org/10.1007/ BF00033159

Borhidi A (1996) An annotated checklist of the Hungarian plant Communities, I. The non-forest vegetation. In: Borhidi A. (ed): Critical Revision of the Hungarian Plant Communities, Janus Pannonius University, Pécs, pp. 43-94

Borhidi A, Kevey B, Lendvai G (2012) Plant communities of Hungary. Akadémiai Kiadó, Budapest

Büdel B (2001) Biological soil crusts in European temperate and Mediterranean regions. In: Belnap J, Lange O (eds) Biological soil crusts: structure, function, and management, 1st edn. Ecological Studies, Springer-Verlag, Berlin Heidelberg, pp 75-86 
Büdel B, Scheidegger C (2008) Thallus morphology and anatomy. In: Nash THIII (ed) Lichen biology, 2nd edn. Cambridge University Press, Cambridge, pp 40-68

Colesie C, Scheu S, Green TGA, Weber B, Wirth R, Büdel B (2012) The advantage of growing on moss: facilitative effects on photosynthetic performance and growth in the cyanobacterial lichen Peltigera rufescens. Oecologia 169(3):599-607. https://doi.org/10.1007/ s00442-011-2224-5

Csintalan Z, Proctor MCF, Tuba Z (1999) Chlorophyll fluorescence during drying and rehydration in the mosses Rhytidiadelphus loreus (Hedw.) Warnst., Anomodon viticulosus (Hedw.) Hook. \& Tayl. and Grimmia pulvinata (Hedw.) Sm. Ann Bot 84: 235-244. https://doi.org/10.1006/anbo.1999.0919

Colesie C, Green TGA, Raggio J, Büdel B (2016) Summer Activity Patterns of Antarctic and High Alpine Lichendominated Biological Soil Crusts - Similar But Different? Arctic, Antarctic, and Alpine Research 48(3):449-460. https://doi.org/10.1657/AAAR0015-047

Demmig-Adams B, Winter K, Krüger A, Czygan FC (1989) Light stress and photoprotection related to the carotenoid zeaxanthin in higher plants. In: Briggs WR (ed) Photosynthesis. Allen R Liss, New York, pp 375-391

Demmig-Adams B, Máguas C, Adams WW, Meyer A, Kilian E, Lange OL (1990) Effect of high light on the efficiency of photochemical energy conversion in a variety of lichen species with green and bluegreen phycobionts. Planta 180:400. https://doi.org/10.1007/ BF01160396

Dietz S, Büdel B, Lange OL, Bilger W (2000) Transmittance of light through the cortex of lichens from contrasting habitats. In: Schroeter B, Schlensog M, Green TGA (eds) New Aspects in Cryptogamic Research: Contributions in Honour of Ludger Kappen (Bibliotheca Lichenologica), J. Cramer, Berlin, Stuttgart, pp 171-182

Ertl L (1951) Über die Lichtverhältnisse in Laubflechten. Planta 39(3): 245-270. https://doi.org/10.1007/BF01909397

Färber L, Solhaug KA, Esseen PA, Bilger W, Gauslaa Y (2014) Sunscreening fungal pigments influence the vertical gradient of pendulous lichens in boreal forest canopies. Ecology 95(6):1464-1471. https://doi.org/10.1890/13-2319.1

Fekete G (1997) Évelő nyílt homokpusztagyepek. In: Fekete G, Molnár Zs, Horváth $\mathrm{F}$ (eds), A magyarországi élőhelyek leírása és határozókönyve. A Nemzeti Élőhely-osztályozási Rendszer, Magyar Természettudományi Múzeum, Budapest, Magyarország, pp 100-102

Friedl T (1987) Thallus development and phycobionts of the parasitic lichen Diploschistes muscorum. Lichenologist 19:183-191. https:// doi.org/10.1017/S002428298700015X

Gallé L (1972-1973) Flechtenvegetation der Sandgebiete der Tiefebene Sudungarns. Móra Ferenc Múzeum Évkönyve 1972(1973):259-278

Gams H (1938) Über einige flechtenreiche Trockenrasen Mitteldeutschlands. Hercynia 1:277-284

Gasulla F, Casano L, Guéra A (2018) Chlororespiration induces nonphotochemical quenching of chlorophyll fluorescence during darkness in lichen chlorobionts. Physiol Plant. https://doi.org/10.1111/ ppl.12792

Gauslaa Y (2014) Rain, dew, and humid air as drivers of morphology, function and spatial distribution in epiphytic lichens. Lichenologist 46(1):1-16. https://doi.org/10.1017/S0024282913000753

Gauslaa Y, McEvoy M (2005) Seasonal changes in solar radiation drive acclimation of the sun-screening compound parietin in the lichen Xanthoria parietina. Basic Appl Ecol 6:75-82. https://doi.org/10. 1016/j.baae.2004.10.003

Gauslaa Y, Solhaug KA (1999) High-light damage in air-dry thalli of the old forest lichen Lobaria pulmonaria - interactions of irradiance, exposure duration and high temperature. J Exp Bot 50(334):697705. https://doi.org/10.1093/jxb/50.334.697
Gauslaa Y, Solhaug KA (2004) Photoinhibition in lichens depends on cortical characteristics and hydration. Lichenologist 36(2):133143. https://doi.org/10.1017/S0024282904014045

Gauslaa Y, Lie M, Solhaug KA, Ohlson M (2006) Growth and ecophysiological acclimation of the foliose lichen Lobaria pulmonaria in forests with contrasting light climates. Oecologia 147(3):406-416. https://doi.org/10.1007/s00442-005-0283-1

Gauslaa Y, Alam MA, Lucas PL, Chowdhury DP, Solhaug KA (2017) Fungal tissue per se is stronger as a UV-B screen than secondary fungal extrolites in Lobaria pulmonaria. Fungal Ecol 26:109-113. https://doi.org/10.1016/j.funeco.2017.01.005

Hájek J, Váczi P, Barták M, Smejkal L, Lipavska H (2009) Cryoprotective role of ribitol in Xanthoparmelia somloensis. Biol Plant 53(4):677-684. https://doi.org/10.1007/s10535-009-0122-z

Hájek J, Barták M, Hazdrová J, Forbelská M (2016) Sensitivity of photosynthetic processes to freezing temperature in extremophilic lichens evaluated by linear cooling and chlorophyll fluorescence. Cryobiology 73(3):329-334. https://doi.org/10.1016/j.cryobiol. 2016.10.002

Heber U, Bilger W, Shuvalov VA (2006) Thermal energy dissipation in reaction centers and in the antenna of photosystem II protects desiccated poikilohydric mosses against photo-oxidation. J Exp Bot 57: 2993-3006. https://doi.org/10.1093/jxb/erl058

Holopainen TH (1982) Summer versus winter condition of the ultrastructure of the epiphytic lichens Bryoria capillaris and Hypogymnia physodes in Central Finland. Ann Bot Fenn 19:39-52

Jensen M (2002) Measurement of chlorophyll fluorescence in lichens. In: Kranner I, Beckett RP, Varma AK (eds) Protocols in Lichenology. Culturing, Biochemistry, Ecophysiology and Use in Biomonitoring. Springer-Verlag, Berlin, Heidelberg, pp 135-151

Kalapos T, Mázsa K (2001) Juniper shade enables terricolous lichens and mosses to maintain high photochemical efficiency in a semiarid temperate sand grassland. Photosynthetica 39(2):263-268. https:// doi.org/10.1023/A:1013749108008

Kitajima ML, Butler W (1975) Quenching of chlorophyll fluorescence and primary photochemistry in chloroplasts by dibromothymoquinone. Biochim Biophys Acta 376(1):105-115. https://doi.org/10.1016/0005-2728(75)90209-1

Kranner I, Beckett R, Hochman A, Nash TH III (2008) Desiccation tolerance in lichens: a review. Bryologist 111:576-593. https://doi.org/ 10.1639/0007-2745-111.4.576

Lange OL (2001) Photosynthesis of soil-crust biota as dependent on environmental factors. In: Belnap J, Lange O (eds) Biological soil crusts: structure, function, and management, 1st edn. Ecological Studies, Springer-Verlag, Berlin Heidelberg, pp 217-240

Lange O, Green TGA (2003) Photosynthetic performance of a foliose lichen of biological soil-crust communities: long-term monitoring of the $\mathrm{CO} 2$ exchange of Cladonia convoluta under temperate habitat conditions. Bibl Lichenologica 86:257-280

Lange OL, Belnap J, Reichenberger H, Meyer A (1997) Photosynthesis of green algal soil crust lichens from arid lands in southern Utah, USA: role of water content on light and temperature responses of CO2 exchange. Flora 192:1-15. https://doi.org/10.1016/S03672530(17)30749-1

Larson DW (1981) Differential wetting in some lichens and mosses: the role of morphology. Bryologist 84:1-15. https://doi.org/10.2307/ 3242973

Leisner JMR, Bilger W, Lange OL (1996) Chlorophyll fluorescence characteristics of the cyanobacterial lichen Peltigera rufescens under field conditions. I Seasonal patterns of photochemical activity and the occurrence of photosystem II inhibition Flora 191: 261-273. https://doi.org/10.1016/S0367-2530(17)30722-3

Lenth RV (2016) Least-squares means: the R package lsmeans. J Stat Softw 69(1):1-33. https://doi.org/10.18637/jss.v069.i01

MacKenzie TDB, Król M, Huner NPA, Campbell DA (2002) Seasonal changes in chlorophyll fluorescence quenching and the induction 
and capacity of the photoprotective xanthophyll cycle in Lobaria pulmonaria. Can J Bot 80(3):255-261. https://doi.org/10.1139/ b02-005

Maxwell K, Johnson GN (2000) Chlorophyll fluorescence - a practical guide. J Exp Bot 51(345):659-668. https://doi.org/10.1093/jexbot/ 51.345 .659

Mishra A, Hájek J, Tuháčková T, Barták M, Mishra KB (2015) Features of chlorophyll fluorescence transients can be used to investigate low temperature induced effects on photosystem II of algal lichens from polar regions. Czech Polar Rep 5(1):99-111. https://doi.org/10. 5817/CPR2015-1-10

Olmo FJ, Vida J, Foyo I, Castro-Diez Y, Alabos-Arboledas L (1999) Prediction of global irradiance on inclined surfaces from horizontal global irradiance. Energy 24:689-704. https://doi.org/10.1016/ S0360-5442(99)00025-0

Pécsi M (1967). A felszín kialakulása és mai képe (Duna-Tisza közi Hátság). In: Pécsi M (ed), Magyarország tájföldrajza. 1. A dunai Alföd. Akadémiai Kiadó, Budapest, pp 214-222

Péczely GY (1967). Éghajlat. In: Pécsi M (ed), Magyarország tájföldrajza. 1. A dunai Alföd. Akadémiai Kiadó, Budapest, pp 222-225

Petruzzellis F, Savi T, Bertuzzi S, Montagner A, Tretiach M, Nardini A (2018) Relationships between water status and photosystem functionality in a chlorolichen and its isolated photobiont. Planta 247: 705-714. https://doi.org/10.1007/s00425-017-2814-5

Pintado A, Sancho LG, Green TGA, Blanquer JM, Lazaro R (2005) Functional ecology of the biological soil crust in semiarid SE Spain: sun and shade populations of Diploschistes diacapsis (Ach.) Lumbsch. Lichenologist 37(5):425-432. https://doi.org/10. 1017/S0024282905015021

Pirintsos SA, Paoli L, Loppi S, Kotzabasis K (2011) Photosynthetic performance of lichen transplants as early indicator of climatic stress along an altitudinal gradient in the arid Mediterranean area. Clim Chang 107:305-328. https://doi.org/10.1007/s10584-010-9989-0

R Core Team (2018) R: a language and environment for statistical computing. R Foundation for Statistical Computing, Vienna https:// www.R-project.org/

Schlensog M, Green TGA, Schroeter B (2013) Life form and water source interact to determine active time and environment in cryptogams: an example from the maritime Antarctic. Oecologia 173 (1): $59-72$

Schreiber U, Bilger W, Neubauer C (1994) Chlorophyll fluorescence as a nonintrusive Indicator for rapid assessment of in vivo photosynthesis. In: Schulze ED, Caldwell MM (eds) Ecophysiology of photosynthesis. Ecological Studies. Springer, Berlin, pp 49-70

Schroeter B, Green TGA, Pannewitz S, Schlensog M, Sancho LG (2011) Summer variability, winter dormancy: lichen activity over 3 years at Botany Bay 778S, Continental Antarctica. Polar Biol 34:13-22. https://doi.org/10.1007/s00300-010-0851-7

Serpe MD, Roberts E, Eldridge DJ, Rosentreter R (2013) Bromus tectorum litter alters photosynthetic characteristics of biological soil crusts from a semiarid shrubland. Soil Biol Biochem 60:220-230. https://doi.org/10.1016/j.soilbio.2013.01.030

Smith CW, Aptroot A, Coppins BJ, Fletcher A, Gilbert OL, James PW, Wolseley PA (eds) (2009) The lichens of Great Britain and Ireland. British Lichen Society, London

Tilk M, Ots K, Tullus T, Mandre M (2018) Ground vegetation diversity and geobotanical analysis in dune pine forests in southwest Estonia. Forestry Studies 69(1):63-74. https://doi.org/10.2478/fsmu-20180012

Timdal E (1991) A monograph of the genus Toninia (Lecideaceae, Ascomycetes). Opera Botanica 110:1-137

Tretiach M, Bertuzzi S, Carniel FC, Virgilio D (2013) Seasonal acclimation in the epiphytic lichen Parmelia sulcata is influenced by change in photobiont population density. Oecologia 173(3):649-663. https://doi.org/10.1007/s00442-013-2654-3

Váczi P, Yngvar G, Solhaug KA (2018) Efficient fungal UV-screening provides a remarkably high UV-B tolerance of photosystem II in lichen photobionts. Plant Physiol Biochem 132:89-94. https://doi. org/10.1016/j.plaphy.2018.08.033

Verseghy K (1971) Angaben uber den Wasserhaushalt einiger Xerotherm-Erdflechten. Ann. Hist.-Nat. Mus. Natl. Hungarici, Pars Bot 63: 83-97

Verseghy K (1994) Magyarország zuzmóflórájának kézikönyve. Magyar Természettudományi Múzeum, Budapest

Veste M, Littmann T, Friedrich H, Breckle SW (2001) Microclimatic boundary conditions for activity of soil lichen crusts in sand dunes of the north-western Negev desert, Israel. Flora 196:465-474. https://doi.org/10.1016/S0367-2530(17)30088-9

Vráblíková H, McEvoy M, Solhaug KA, Barták M, Gauslaa Y (2006) Annual variation in photoacclimation and photoprotection of the photobiont in the foliose lichen Xanthoria parietina. J Photochem Photobiol B Biol 83:151-162. https://doi.org/10.1016/j.jphotobiol. 2005.12.019

Wedin M, Maier S, Fernandez-Brime S, Cronholm B, Westberg M, Grube M (2015) Microbiome change by symbiotic invasion in lichens. Environ Microbiol 18(5):1428-1439. https://doi.org/10.1111/14622920.13032

Wickham H, Romain F, Lionel H, Müller K (2018) Dplyr: a grammar of data manipulation. R package version 0.7 .8 . https://CRAN.Rproject.org/package $=\mathrm{dplyr}$

Wirth V, Hauck M, Schultz M (2013) Die Flechten Deutschlands. Ulmer, Stuttgart

Wu L, Zhang G, Lan S, Zhang D, Hu C (2014) Longitudinal photosynthetic gradient in crust lichens' thalli. Microb Ecol 67(4):888-896. https://doi.org/10.1007/s00248-014-0366-9

Publisher's note Springer Nature remains neutral with regard to jurisdictional claims in published maps and institutional affiliations. 